\title{
The Pre-colonial Yoruba Education System: Catalyst Against Immorality
}

\author{
Layo Ogunlola \\ University of Ilorin, Nigeria \\ layoogunlola@gmail.com
}

\begin{abstract}
The notion that Africans in general have no literature of their own has been severally debunked as false assertion. Awólàlú (1979) describes it as 'erroneous', a thought borne out of prejudice, malice and bias (3). Among these is their method of training both the young and old in the ways and traditions of the people. The Yorùbá had a system of education referred to as ìlànà ètò èkó ibílè (traditional or indigenous system of education). Even though the said system of education was not documented, it is not only flexible enough to conserve the tradition and culture of the people, it has also proved adequate in transmitting the cultural heritage from generation to generation using the mother-tongue as a tool. This paper examines the effectiveness of this traditional system of education in the development of the pre-colonial Yoruba society especially in terms of moral diligence. The paper critically analyzes the system and concludes that a society that is morally bankrupt cannot develop, hence the need for a system of education that emphasizes moral training such as the Yorùbá traditional system of education as compared with the Western system of education, which lays emphasis on jobs. The paper concludes that if the formal education system can prioritize moral training by tailoring the curriculum towards this objective, the problem of high moral decadence level currently ravaging our various societies may continue and this will not do the societies any good.
\end{abstract}

\section{Introduction}

Every nation has its own established moral philosophy which may differ from one society to the other. The said moral philosophy monitors and directs people's ways of doing things. One of the means of inculcating these moral values in the citizens is through traditional education curriculum which 
emphasizes training of good character. The Yorùbá people for example emphasizes that moral education should start from the home which they regard as the first 'school' of the child. This is where the foundation is laid. Therefore, it will not be out of context to say that this system of education is a panacea for societal advancement in all ramifications. Fáfunwa, B. (1974) asserts that:

If Africa is to make progress in moving from the eighteenth century into the late twentieth century, unconventional approaches to science and education unprecedented in world history will have to be devised. To achieve this objective, the foundation should be laid at the earliest stages of the education of the young as well as on other levels of education - elementary, secondary, technical, university, adult and teacher education - through general and special education (4).

We would like to support this notion because we believe that if the education of the child in laid on solid foundation, such a child will thrive. This is exactly the focus of the Yoruba traditional education system. Fafunwa goes further to say that by so doing, "the child and the adult would be able to manipulate simple gadgetry through work of hand and eye which should buttress or supplement mind and heart" (5). We want to agree with Fafunwa because whatever a child is used to is what he grows with and exhibits at adulthood. A statement credited to Thomas Fowell Buxton, quoted in Taiwo (1981) says: "It is the Bible and the plough that must regenerate Africa, as well as the development of the local languages and the identification and training of evangelical leaders" (7). This statement negates the views of Yòlóyè (2009) that, "the former education seems to have de-emphasized morality which is at the heart of Yorùbá traditional education" (30). In the same vein, İsòlá (2009) is of the opinion that:

Our preference for foreign cultural materials, including literature and even religions is also one of the barriers affecting genuine development $[. .$.$] the$ cultural education of the child cannot succeed in a holistic approach to cultural reorientation in the society to create a friendly atmosphere for the child to internalize the humane virtues in our cultural heritage (100).

This essay examines how effective the traditional system of education is in the development of a society especially in terms of moral diligence. The paper critically analyzes the system and concludes that a society that is morally bankrupt cannot develop, hence the need for a system of education that emphasizes moral training such as the Yorùbá traditional system of education. 


\section{Yorùbá Traditional Education System}

It is not an overstatement to say that Yorùbá traditional education existed before the advent of western or modern education. This kind of education is referred to as the informal or traditional method of training a child to develop into adulthood. Calling it traditional does not mean that it is no more in existence. The process, though not documented, was firmly established in their systems of training. Awóníyì (1978) explains that the Yorùbá traditional system of education before the coming of the colonial masters has its main objective as making an individual an omolúàbí. He writes:

Before colonization, there was a system of education known as the Yorùbá traditional or indigenous education system (ètò èkó, ibílè, Yorùbá). The main objective was to make the individual an 'ómolúàbi' (1).

He goes further to say that:

The Yorùbá traditional or indigenous education which had been operating for several years before the contact with Europeans (before the formal school system) for instance has its pattern and it is flexible enough to conserve and transmit the culture, tradition, and experiences of a particular society. It also proofs adequate in transmitting the colonial heritage from generation to generation through the use of the mother tongue language. This differentiates it from the formal education which involved a systemic and organized schooling in planned institutions of learning at whatever level. (p.1).

Awoniyi (1978) asserts further that "the mother tongue is the manifestation of traditional education per se. It is the way in which each human infant is transformed into the finished adult and into complicated individual of his community. It is a lifelong process where the whole society is the 'school of life'" (2). It is an on-going process which involves the individual and his society. In this situation, the goals of the society become the goals of the individual and vice versa. This is in line with Dasylva's (2017) view that: "The philosophy of indigenous education was very pragmatic, and it was designed to form a gateway to the life of the society" (713). He goes further to say that:

The Yorùbá indigenous education is the process by which the society attempts to preserve the accumulated knowledge, skills and attitudes in its cultural setting and heritage to foster continuously the well-being of the people. The curriculum, though not documented, was very elaborate and 
embraced all aspects of human development. These range from mental broadening, physical fitness, moral uprightness, and religious deference to good social adjustment and interaction (713).

It is worthy to note that character training and religious education are the two major objectives of Yorùbá education. It is tailored towards producing an omolúàbí (a person with good character). Awóníyì (1978) attests to this when he writes that "education is cultural transmission" (15). This is done through the child's language (the mother tongue). Awoniyi asserts that:

The mother-tongue that he learns in his first six years of life is not a garment that he can put off when he dons his school uniform. Rather, it is part of the stuff of which his mind is built, it embodies the ideas and attitudes he has gained from his environment, [...] it is the language through which he thinks, dreams, cherishes, loves, scolds and learns (15).

It is unfortunate that at the introduction of school education, the use of the child's language was forbidding for the child. The trend continues today, thus in schools, non-conventional laws are made against the use of the mother-tongue. The Yoruba child is punished for conversing in the mother-tongue. The omolúàbi concept which describes an individual who is responsible, capable of taking care of him or herself, and contributes positively to the development of the society is no more taught to the child. Bánjo (2009) opines: "Indiscriminate cultural borrowing may produce deleterious effects, and the degree of impersonality which results from lack of diverse cultures may subtly encourage disloyalty to one's own culture, when little is done to reinforce that culture" (135).

This is not to say that it is a crime to borrow culture, however, we should not borrow culture at the detriment of our own culture. In the past, good morals among the Yorùbá people included respect for elders, humility, truth, kindness, chastity before marriage, dignity of labor, courage, bravery, honesty and hard work (Adéyẹmí, 2008:118). They do everything possible to instill these qualities in the younger ones through their oral literatures such as proverbs, poems, folk stories, myths and legends, to mention just a few. Today, however, the reverse is the case. The change, according to Bánjo (2009), has devastating effects on the populace: He asserts, "For many, fraud has become the way of life, manifesting itself, for example in fake drugs and piracy. Some of the perpetrators have even infiltrated foreign countries and are giving the country a bad name" (139). This quote attests to the fact that the morality level of the people is fast dwindling today. This may be as a result of the influx of foreign cultures and civilization. Following Longnore, Awóníyì (1975) makes 
the following analysis: "If a man does away with his traditional way of living, and throws away his good customs, he had better first make certain that he has something of value to replace them" (365). It is doubtful if the Yorùbá people are conscious of this fact. Unfortunately, today, Yorùbá society has lost almost all its good customs but it is doubtful if the ones they have acquired to replace them have the proper value.

The idea of cultural rejuvenation had been in practice before the introduction of formal education. It was the duty of every member of the society to enforce the observance of the moral rules. Akínjógbìn (2009: 117-120) groups this into three different categories namely: èkó ilé (home training), ècó, isé, (occupational training) and èkó ìlú (communal training).

\section{Èkó llé (Home Training).}

Adeyęmo, (1965) asserts:

The first station where the child enters the world hence its influence is very strong in the training of the child. All psychologists agree that "the mother is the child". Napoleon was said to have stressed the importance of the mother when on one occasion, he said that the greatest need of a country is a mother. The first impression of the child reflects from the mother, followed by the nurse, the brothers, the sisters, the father and other members of the family. The child takes its model of everything from the home. He copies everything he sees these people do. The home is his world. It either leads the child's life to success or it mars it. The home provides the child with necessary equipment to fit him for his proper place in the society and he is guided properly for his future career. If the home fails in its duties, then the future is bleak for the child (11).

There is no gainsaying the fact that the child spends more time at home more than elsewhere especially with the mother. The mother therefore is in a better position to mentor and monitor the child's behavior. The father only gives support.

The main focus of this kind of training is to inculcate good moral values in every individual. The training starts from youth, the language being the first tool. The said Yorùbá traditional education starts from the womb when a pregnant woman will be warned and protected from anything that can hinder her safe delivery. From infancy, the child is taught the language used for greeting, respect for elders, he learns about myths and taboos, from where he brings out different moral lessons. 
The training of good character in a child is the joint responsibility of the entire members of the society. It is not singularly done. The Yorùbá says àgbájo, owón ni a fi n' so àyà meaning 'collective effort brings successes. In the Yorùbá traditional system of education, all parents want their children to be upright, honest, kind and helpful to others. They spare no effort to instill these qualities in them. For this reason, home training is fundamental in Yorùbá moral philosophy. Through home training, the child knows everything about his lineage, his praise poetry, the roles of the male and the female in the society and so on. A child who is not given home training is called àbíikó, while the one who refuses to accept home training is called àkóòggbà.

The Yorùbá have different ways of scolding the child who refuses to yield to good character training. They do this not only through language but also through paralinguistic models such as ear and eye contact before resorting to the use of the cane. Yorùbá also believe in the Biblical saying that: àyà omodé ni 'wèrè di sí, pàsán ni a fi n'já a literally meaning that the mind of the infant is full of evil; however one has to resort into the use of cane to remove it. This implies that corporal punishment may be applied to tame an unyielding child. This is born out of the Yorùbá belief that: omo tí a kò kó, ni yóó gbé ilé tí a kó, tà meaning an untrained child sells out the house one builds.

The Yorùbá family system can be grouped into two namely: the nuclear family, which comprises the father, the mother and their children, and the extended family, which include uncles, aunts, cousins, brothers, sisters, grandfathers, grandmothers and so on. The head of the family is referred to as the baálé or olórí ilé. The training of the child, as we earlier mentioned, is the joint responsibility of the entire family/community. Yorùbá people also believe in the saying "spare the rod and spoil the child" or the biblical saying that one should train the child in order to have peace of mind. In Yorùbá society, a stubborn and unyielding child is referred to the baálé for punishment. This is so because they believe that a child fears the father than the mother who pampers the child and nobody frowns at whatever punishment is meted on the child by the baálé.

The iyáálé (usually, the oldest woman in the compound), takes care of pregnant women and teaches the dos and don'ts to follow during pregnancy. On delivery day, she leads other wives to deliver the woman of her baby. It is the duty of the iyáálé to narrate the indigenous stories of the family to the children in the compound after the day's work. She engages the children in folk stories especially, the àló onítàn the Tortoise Tales and Co-wife Tales. The objective mainly is to teach the children to imbibe the spirit of good character (omolúàbí) which used to be the cornerstone of the Yorùbá traditional education system as earlier mentioned. She also tells stories of past events within or outside the community. 
The situation today is different. In schools, teachers are forbidding from punishing erring pupils/students and at times they are prosecuted for punishing school pupils. In this area, the parents are also not helping the matter. Instead, they spare the rod, thus spoiling the child. No wonder why there is rapid increase in the numbers of school drop outs who eventually become touts, hoodlums, posing a serious threat to the peace and stability of the society. This is because the school curriculum is not tutored towards imbibing good character but towards securing white kola jobs.

Our experiences have shown that parents have no time for the child's training. In cities like Lagos (Nigeria), most parents have their jobs as their priority. They go out very early and before the child wakes up and comes back after the child had slept. Today there is nothing like storytelling, moonlight plays and the like. This no doubt cannot benefit the society positively.

\section{Ėkó Isé (Occupational Training)}

The Yorùbá also operate the apprentice system. This idea is borne out of the belief that everybody must provide a means of livelihood for himself or herself. To them, an idle hand is the devil's instrument. To this end, they send their children out as apprentices to learn a trade. It is, however, important to note that it is not just leasing out the child for apprenticeship that matters, but that such a child is leased to a master who is expected to be morally blameless. This is because it is believed that while the child may take after his parents physically, he is expected to take after his master (with whom he interacts mostly) morally or professionally. Chief among the lead skills expected to be inculcated in the child by the master is diligence.

The Yorùbá like to teach their children to work hard. They believe in the saying that there should be no food for a lazy man. Hence a lazy man has no respectable place in the society. He is subjected to ridicule. Reference can be made to J.F. Odúnjo's poem in his book titled Àkójopò Ewì Aládùn that was popular and often recited by school children in the past which condemns laziness. It goes thus:

Ise lòogùn issé

Múra sisé òrée mi

Isé ni a fi n' di eñi gíga

Bía kò bá r'éni fè̀yintì

Bíòle là á rí

Bí a kò bá réni gbékè̀lé

A tera móséséni

Iyá lè lówó lówó 
Kí baba lésin léèàn

Bí o b'gbójú lé won

O té, tán ni mo so fún o.

Iyà n' be f'ómo tí kò gbón

Ekún n' be fómo tó n sá kiri

Má fòwúrò seré òréè mi

Múra sísé, ojóón lo lodunjo 1961:1).

To work is the antidote for poverty

Be steadfast in your work my friend

It is work that makes one great

If you don't have anyone to lean on

You will appear like a lazy person

If you don't have someone to rely on

You take your work seriously

Your mother may be in money (rich

And your father stingingly rich

If you rely on them

You are disgraced, I tell you

Suffering awaits a senseless fellow

Sorrow awaits the child messing around

Do not toy with your early days, my friend

Be steadfast in your work, time is moving.

The İjálá chanters also use their art to condemn laziness:

Alápá má sisé, baba òkú òle,

Àkísà rè jigbinni, nílé aláro (from writer's research).

The one with an idle hand, father of lazy people

His rags would be plenty, in the dyer's shop

These excerpts and many others tell us the Yorùbá worldview about laziness. The question is: Where are those verses and chants today? They have become a thing of the past.

\section{Èkợillú (Communal Training)}

In the past, the king would bring together pupils of the same age group. They form societies named according to the major incidents that happens during their time of birth. When these pupils grow up, they engage in communal work that suits their age groups. As they grow, their community 
assignment becomes more tedious. Those who are above the age of going to war eventually become the elders of their respective communities. The advantage therein is that the youths are acquainted with community developmental processes before they become adults. It is also an avenue for unifying people from different family thus encouraging cooperation among the people.

The whole community was involved in one community project or the other. These include projects like clearing/mending the road that leads to the community stream, cleaning the community market places, clearing the king's farmland and others. It is worth mentioning that the duties of the male are different from those of the females. For instance, when the males clear the weeds, the females pack them. The females take care of sweeping, and so on.

It is a must for everybody to participate fully in all developmental projects and anybody who fails to participate is fined, his capability or non-capability to pay the price notwithstanding. Whosoever disobeyed this directive was first reported to the baálé who acts as the first 'court of law'. If the erring person proves stubborn, his case is taken to the oba's court (which is the 'Supreme Court') and whatever judgement the king delivered was final.

Omolúàbi (good moral principles) among the Yorùbá include the following: chastity before marriage, selflessness, hospitality, generosity, kindness, rectitude, honesty, reliability, responsibility/trustworthiness, straight-forwardness., protection of women as weaker sex, honor and self-respect to parents, elders and those in authority, shunning acts of violence, drug abuse, cheating in any form and many others.

The virtues mentioned here are the products of being an omolúàbí. No one who lacks these virtues is considered as an omolúàbi in the Yorùbá society. The Yorùbá prefer to be childless to having a morally bankrupt one who will bring shame to the family or tarnish the image of the family. Hence, they say àkúkúùbí, ó sàn ju èyí ràirài meaning, "not having a child at all is better than having a 'good-for-nothing' child."

Among the Yorùbá, omolúàbi principle is not compromised. There is the belief that whatever a person becomes or has, if he does not possess the omolúa bi qualities, such a person is a failure in life. This implies that it is not necessarily the highly placed, the rich or popular people who are referred to as omolúàbí, rather it is anyone who displays good character as approved by the society he or she lives.

Fáfúnwá, (1974) states that: "In traditional Yorùbá society, all parents want their children to be upright, honest, kind and helpful to others and will spare no pain to instill these qualities" (4). This implies that anti-omolúàbí behaviors are regarded as vice. Anybody who exhibits such behavior is given derogatory names such as omolangidi comparing such a person to a wooden dull, and not given any recognition in the society. 
Adéríbigbé (1995) writes on the relationship between religion and morality. In his opinion, the average believer has come to assume that the influence of religion on the behavior of an individual goes a long way to determine the sort of moral life he lives. To a religious believer, he asserts, separating religion from morality amounts to removing God from the scheme of human life. African religion, according to him, upholds the strong belief that the Supreme Being and the divinities have set the standard of morality. By this statement, Adéríbigbé (1995) believes that religion has vital roles to play in molding the morals of the people. No wonder he says:

This is why African Religionists have always desisted from crimes to avoid incurring the wrath of the divinities that will not leave the breaking of covenant unpunished. To the African Religionists, being moral would be the expressed fulfillment of the covenant relationship between man and the creator (297).

Adéríbigbé suggests that religious belief must be seen as the foundation of moral belief. To separate the two is neither acceptable nor desirable. In the same vein, Egudu (1972) argues that, "Since good attitude or behaviour towards fellowmen is one of the very necessary conditions for religion, it has to follow naturally and logically too that there cannot be any morally good attitude or act which does not, to that extent, share in the nature of religion" (47).

This notion is supported by İdòwú (1972) who says that: "Man's concept of the Deity has everything to do with what is taken to be norm or morality. God made man and it is He who implants in him the sense of right and wrong" (101). Òlátúnjí (1979), also, asserts that:

In most traditional African societies, the kind of dichotomy of divorce of religion and literature does not exist. Among the Yorùbá, for example, literature enshrines the theology and cosmology of the people and reflects their ethics and morale (52).

What Olátúnjí is saying here is that literature reflects the moral state of a society and that within the Yorùbá society; religion has many roles to play in determining people's behavior.

In as much as we believe that religion shapes people's moral, it is also evident that a person who cannot be regarded as being religious can be morally good. It is also possible for a person who claims to be religious to be morally bankrupt. This opinion, according to Adéríbigbé, (1995:293) is in line with the Humanist Philosophers such as Soyínká, who believe that: It is perfectly possible to be moral without being religious whatsoever. This is because moral 
convictions can be correct and proper without depending on any religious conviction or practice. Some people, who are supposed to use their positions in the society to improve the moral standard of the people, use them to commit evil. No wonder, the Yorùbá will say așo, n'lá kó, ni èèyàn n'lá meaning the size or quality of one's dress does not determine his greatness. This is what the humanists like the late Tai Solarin believed. He is quoted as saying: "The more we see religious heat being turned on in Nigeria, the more we see corruption, nepotism, of man's inhumanity to man, spreading across our horizon and making the firmament thicker still" (Sunday Tribune, November 11, 1990, p. 4).

Awoniyi, (1978), observes that "Folklore is the cornerstone of Yorùbá oral literature with immense value in Yorùbá education" (9). This implies that folklore plays very important role in the Yorùbá traditional education system. He illustrates this with few examples of the Yorùbá teachings on truthfulness, endurance, patience, jealousy, greed and the likes. Apart from the moral training, the child is developed linguistically and in the area if intelligence development through rhymes. For example, the child is taught the Yorùbá numerals 1-10 through rhymes such as this:

Ení bí ení, l'omodé n' ka’wó

Ėji bí èji, làgbà ń tayò

Ėta bi èta eni tó ta’ni là á ta

Érin bi èrin, eni tó rín 'ni là á rín (from writer's research).

The child counts money one by one

The elder plays the ayò game two by two

Three by three, it is the person who slides you that you slide

Four by four, you mock the person that mocks you.

In the excerpt above, the child is educated to understand and identify numbers 1-10. While reciting this verse, the child is not only learning the Yorùbá numerals, he also has the opportunity to mix with his age groups. At the same time, the child's intelligence is being developed.

Through folk stories, proverbs, the child is also acquainted with the Yorùbá virtues and vices. He or she is encouraged to imbibe the virtues and run away from the vices. The virtues include respect for the elders, customs, traditions and constituted authorities. For example, the Yorùbá will say àifàgbà fénikan ni kò jé káyé ó gún meaning failure to give deserved respect to the elders is the reason for most conflicts in the world. The vices include: murder, stealing, lying, backbiting, backsliding etc. 
It is not only the young ones that are cautioned on the need to behave well, the elders are also warned not to exceed their bound. Hence, the saying àgbà tí kò tijú láti gun kétékété, kétéké,té, náà kò nií tijú láti là á mólè, (the elder who fails to caution the way he rides a horse, the horse will not hesitate to fall him).

On truthfulness, Yorùbá observe that most people are not truthful and the few who are truthful are hated by their people. Hence, the saying: òtító dójà ó kùtà, owó lówó ni a n' ra èké meaning 'truth gets to the market, nobody buys it, if you have your money you can easily purchase lie. Here, 'truth' and 'lie' are personified in order to tell us how much the people prefer telling lies to telling the truth.

On very important issues, the child is taught to reflect on how circumstances of the past may shape the condition of the present and the hopes of the future. Awoniyi (1978:11) asserts that this is a cardinal element of Yorùbá education to honor the past before embarking on a new project.

\section{Findings}

In this paper, we have been able to discuss the prospects of the traditional system of education using the Yorùbá as our yardstick. Our findings reveal that:

(i). The introduction of foreign religions, ideas and cultures have bastardized the indigenous education system which in our opinion has more prospects for the society than the imbibed foreign system.

(ii). Because Africans in general and the Yorùbá in particular have totally abandoned their traditional system of education, the importance of good morals ìwà omolúàbí has been relegated to the background. There has been noticeable reduction in the people's commitment to morality. The society is morally bankrupt.

(iii). The abandonment of the use of Yorùbá oral literature such as proverbs, folk stories, myths, legends, tales, dos and don'ts, taboos etc., in the teaching of moral values have had devastating effects on the development of our societies bearing in mind that a society that is morally bankrupt cannot achieve any meaningful development. In the absence of this, immorality of various degrees is encouraged. Every day, we read and hear of different kinds of evil being perpetrated and the leaders seem to be indifferent to them.

(iv). Because of their disregard for moral diligence, most rulers see no reason why the tradition should be followed. 
(v). Most parents leave the training of their wards in the hands of house maids, nannies, and even school teachers yet they would want these people to spare the rod no matter the child's level of moral decadence.

\section{Conclusion}

The paper concludes that the adoption of the indigenous (traditional) system of education is still relevant to societal development. It is of importance that the teaching of Yorùbá cultural traits especially moral education which was the main objective of the traditional system of education is emphasized and given priority attention in the new education system. As earlier reiterated, the roles of Yorùbá oral literature in the education of the young ones are enormous. One may be forced to ask such questions as: 'what happens to the Yorùbá oral literature? Where are they? Why should they be discarded? What happens with idea of moon light plays and the lessons therein?

Yorùbá literature always emphasizes the principle of omolúàbí which, interestingly, has been one of the philosophies of the Yorùbá people. Diverse expositions emanate in the quest to unravel the philosophical dispositions of a people. Adéyẹmí (2008:117), quoting Russell (1961) opines that: "to understand an age or a nation, one must understand their philosophy" (11). In other words, the philosophy of a people does much to determine the circumstances of their lives. This opinion is in line with Oládipò's (1998) view that: "To understand a people through their cultural expressions, one must judge each culture both in terms of the basic assumptions about reality in terms of its goals" (34).

The philosophy of a society, therefore, is a guide to life and it varies from one culture to another. Omoregbe's (2001) addition to this is that: “Through the ages, philosophy has played a vital role in the development of the society. The philosophy of each society influences the people of that society" (3).

We support Omoregbe's view that the philosophy of a people largely influences the social, economic, political and religious life of the people. The philosophy of this study is that of morality (omolúàbí), the status of its degeneration which is having negative impact on the essences of life in the contemporary Yorùbá society and, indeed, the world at large.

Finally, we want to emphasize the need to amend the school curriculum in line with the culture of the societies that use them. All stakeholders in the education sector should join hands in moving the society forward through the adoption of an education policy that would be beneficial to the society. The development of the child and the society morality should be the main target of whatever education system a society will adopt. It is certain that a morally bankrupt society cannot experience any meaningful development. 
We are pretty sure that if Nigeria education system is tailored towards making the individual an omolúa $i$, there is no doubt that the country as a whole will benefit immensely.

\section{References}

Adebolá, B. D. (2017). "Family, Indigenous Education System, and Discipline". In Toyin Falola and A. Akinyemi (eds). Culture and Customs of the Yorùbá. Austin: Pan African University press.

Aderibigbe, I.S. (1995). "The moral issues in African religion." Studies in Religious Understanding in Nigeria. 4.1: 292-312.

Adeyemi, L. (2008). "The portrayal of moral philosophy in Yorùbá literature". ĖDÊ: Journal of Language, Literature and Culture. 3: 117-136.

Awoniyi, T.A. (1978). Yorùbá Language in Education 1846 -1974 A Historical Survey. Ibadan: Ibadan University Press.

Awoniyi, T.A. (1975). “Omolúàbí: The fundamental basis of Yorùbá education. In Wande Abimbólá, (ed). Yorùbá Oral Tradition. Ilé-Ifè̀: Department of African Languages and Literature, University of Ifè, pp. 356-388.

Banjo, A. (2009). "Tertiary education and imperatives for productive labour". In A. Ogundeji, \& A. Akangbe, (eds). Omoluabi: Its Concept and Education in Yorùbáland. Ibadan: Ibadan Cultural Studies Group, pp. 129-142.

Egudu, R.H. (1972). "Can there be morality without religion?" Faith and Practice. Vol. 1, No. 2: 1-45.

Fafunwa, A. B. (1974). History of Education in Nigeria. London: George Allen \& Unwin

Fafunwa, B. (1974). New Perspectives in African Education. London: Macmilan Education Limited.

Hans, N. (1980). Comparative Education: A study of Educational Factors and Traditions. London: Routledge \& Kegan Paul.

İsòlá, A. (2009). "Yorùbá Culture in Education." In A. Ogundeji, \& A. Akangbe, (eds.). Omolúàbi: Its Concept and Education in Yorùbáland. Ibadan: Ibadan Cultural Studies Group, pp.129-142.

Odunjo, J. F. (1961). Àkójopò Ewì Aládùn. London: Longmans, Green.

Ogundeji, A. \& A. Akangbe. (2009). "Introduction." In A. Ogundeji, \& A. Akangbe, (eds.). Omolúàbi: Its Concept and Education in Yorùbáland. Ibadan: Ibadan Cultural Studies Group, pp.1-10.

Ogunsheye, F. A. (2009). "Welcome Address". In A. Ogundeji, \& A. Akangbe, (eds.). Omolúàbí: Its Concept and Education in Yorùbáland. Ibadan: Ibadan Cultural Studies Group, pp. xv. 
Ogunsina, B. (1995). “Colonialism and the Yorùbá Writer: A Study of Ládélé’s İgbà ló dé." In O. Owólabí, (ed.). Language in Nigeria: Essays in honour of Ayò, Bámgbósé, Ibadan: Group Publishers, pp. 297-310.

Ojo, O. (2005). İjàpá Tìrókò Oko, Yánníbo. İkejà: Longman Nigeria plc.

Oladipo, O. (1998). The idea of African philosophy. İbàdàn: Hope Publications.

Olatunji, O.O. (1979). "The Yorùbá oral poet and his society" Research in African literature. 10.2: 51-70.

Omoregbe, J.I. (1979). Ethics: A Systematic and Historical Study. London: Global Educational Service.

Omoregbe, J.I. (1990). Knowing Philosophy. Lagos; Joja Educational Research and Publishers Limited.

Omoregbe, J.I. (1993). A Philosophical look at Religion. Lagos; Joja Educational Research and Publishers Limited.

Omoregbe, J.I. (1994). An Introduction to Philosophical Jurisprudence. Lagos; Joja Educational Research and Publishers Limited.

Omoregbe, J.I. (2001). Philosophy of Mind: An Introduction to Philosophical Psychology. Lagos; Joja Educational Research and Publishers Limited.

Taiwo, C.O. (1980). The Nigerian Education System. Ikeja: Thomas Nelson Nigeria Ltd.

Yoloye, A. (2009). "The philosophy of Nigerian education system and relevance to the concept of Yorùbá 'omolúàbí." In A. Ogundeji, \& A. Akangbe, (eds.). Omolúàbí: Its Concept and Education in Yorùbáland. Ibadan: Ibadan Cultural Studies Group, pp.29-55. 